\title{
CD14 (C-159T) polymorphism is associated with increased susceptibility to SLE, and plasma levels of soluble CD14 is a novel biomarker of disease activity: a hospital-based case-control study.
}

Aditya K Panda ${ }^{1}$, Rina Tripathy ${ }^{2}$, Bidyut K Das ${ }^{3 *}$

${ }^{1}$ Department of Bioscience and Bioinformatics, Khallikote University, Transit Campus: GMax Building, Konisi, Berhampur, Odisha, India, 761008.

${ }^{2}$ Department of Biochemistry, S.C.B. Medical College, Cuttack, 753007, Odisha, India

${ }^{3}$ Department of Medicine, S.C.B. Medical College, Cuttack, 753007, Odisha, India

*Address of Correspondence:

Dr. Aditya K. Panda

Department of Bioscience and Bioinformatics

Khallikote University

Berhampur, Odisha, India

Phone: +919439999900

E mail: $\underline{\text { adityarmrc@gmail.com }}$

And

Prof. Bidyut K Das

Department of Medicine

S.C.B. Medical College

Cuttack, 753007

Odisha, India

E mail: bidyutdas@hotmail.com 
medRxiv preprint doi: https://doi.org/10.1101/2020.06.19.20136119; this version posted June 20, 2020. The copyright holder for this preprint (which was not certified by peer review) is the author/funder, who has granted medRxiv a license to display the preprint in perpetuity.

All rights reserved. No reuse allowed without permission.

\section{ABSTRACT}

Background: Cluster of differentiation 14 (CD14) plays a crucial role in the innate immune response of the host in protection against various pathogens. The importance of soluble CD14 in autoimmune disorders has been described in different populations. However, the role of sCD14 in systemic lupus erythematosus (SLE) is poorly understood. Further, the association of functional variants at the promoter region of the CD14 gene $(-159 \mathrm{C}>\mathrm{T})$ with susceptibility to SLE or disease severity needs to be defined.

Methods: Two hundred female SLE patients diagnosed on SLICC classification criteria and age, sex, matched healthy controls were enrolled in the present study. PCR-RFLP method was used to genotype CD14 (C-159 T) polymorphism. Plasma levels of IFN- $\alpha$, TNF- $\alpha$, and sCD14 were quantified by ELISA.

Results: Prevalence of mutant genotypes (CT and TT) and minor allele of CD14 (C-159T) polymorphism was significantly higher in SLE cases compared to healthy controls $(\mathrm{CT}: \mathrm{P}<0.0001 ; \mathrm{OR}=3.26, \mathrm{TT}: \mathrm{P}<0.0001 ; \mathrm{OR}=3.39 ; \mathrm{T}: \mathrm{P}=0.0009, \mathrm{OR}=1.62)$. Further, lupus nephritis patients had a higher prevalence of homozygous mutants (TT) and mutant allele (T)(TT: $\mathrm{P}=0.0002, \mathrm{OR}=8.07 ; \mathrm{T}: \mathrm{P}=0.001, \mathrm{OR}=1.32$ ). SLE patients displayed significantly increased plasma sCD14, TNF- $\alpha$, and IFN- $\alpha$ levels in comparison to healthy controls. These cytokines were significantly elevated in patients of lupus nephritis compared to those without kidney involvement. Interestingly, sCD14 levels correlated positively with SLEDAI-2K scores and 24 hours proteinuria. 
medRxiv preprint doi: https://doi.org/10.1101/2020.06.19.20136119; this version posted June 20, 2020. The copyright holder for this preprint (which was not certified by peer review) is the author/funder, who has granted medRxiv a license to display the preprint in perpetuity.

All rights reserved. No reuse allowed without permission.

Conclusion: CD14 (C-159T) polymorphism is associated with an increased predisposition to the development of SLE and lupus nephritis: sCD14 is a promising novel biomarker for assessing disease activity and lupus nephritis.

Keywords: systemic lupus erythematosus, lupus nephritis, gene polymorphism, CD14, IFN- $\alpha$.

\section{INTRODUCTION}

The systemic lupus erythematosus (SLE) is a complex, autoimmune disease characterized by chronic inflammation in various tissues of the body(1). Although the exact mechanism of induction of autoimmune diseases is unknown, dysregulation of the adaptive immune system has been attributed to autoantibody production(1). Both innate and adaptive immune systems closely interact with one another, with adaptive immunity being controlled by the components of innate immunity (2). The innate immune system can be triggered by various infectious agents which possibly play a significant role in the pathogenesis of $\operatorname{SLE}(3)$.

Toll-like receptors (TLRs), present on the cell surface of innate immune cells, recognize microbial motifs called pathogen-associated molecular patterns (PAMPs) and activate the downstream signal transduction pathways(4). There are several lines of evidence to suggest that TLR4 by itself cannot act as a receptor for lipopolysaccharide (LPS) for the induction of downstream signaling. It requires other molecules viz. LPS- binding protein (LBP), myeloid differentiation protein 2 (MD-2), and CD14 for effective signaling (5). The critical role of CD14 in LPS signaling has been well documented - CD14 knockout mice are resistant to LPS challenge (6). The addition of sCD14 enhanced TLR4 mediated NFK-B activation in the HEK293 cell line (7). 
medRxiv preprint doi: https://doi.org/10.1101/2020.06.19.20136119; this version posted June 20, 2020. The copyright holder for this preprint (which was not certified by peer review) is the author/funder, who has granted medRxiv a license to display the preprint in perpetuity.

All rights reserved. No reuse allowed without permission.

Since CD14 plays a crucial role in the innate immune system and infections have been an important triggering factor for the development of SLE, a small study reported by Nockher et al in 1994 showed elevated sCD14 levels in patients of SLE; active SLE patients displayed significantly higher levels compared to patients with inactive disease. Furthermore, sCD14 levels correlated positively with disease activity scores (8).

Differential levels of sCD14 have been reported in healthy individuals of different populations. Variations in plasma sCD14 levels have been attributed to the genetic makeup of the subjects and associated with various functional gene polymorphisms. A polymorphism at the promoter region (-159) leading to a C-to-T change at that position was associated with increased CD14 mRNA expression (9). Homozygous mutants (TT) were associated with higher levels of soluble and membrane-bound CD14 (10, 11). Since CD14 (C-159T) polymorphism up-regulates levels of sCD14, we hypothesized that the variant might be associated with an increased predisposition to SLE as well as to its severity. We addressed this hypothesis by enrolling SLE patients admitted in a tertiary care center and healthy controls from Odisha, an Eastern state of India; CD14 (-159) polymorphism was genotyped, plasma levels of sCD14 inflammatory cytokines were quantified and analyzed for association with SLE and its disease severity (SLEDAI-2K).

\section{Materials and Methods:}

\section{Patients and controls}

SLE is a chronic inflammatory disorder and mostly affects females(12). Female SLE patients attending rheumatology clinic and/or admitted to SCB Medical College, Cuttack, Odisha, India, were enrolled in the present study. The diagnosis of SLE was based on the SLICC 2012 
medRxiv preprint doi: https://doi.org/10.1101/2020.06.19.20136119; this version posted June 20, 2020. The copyright holder for this preprint (which was not certified by peer review) is the author/funder, who has granted medRxiv a license to display the preprint in perpetuity.

All rights reserved. No reuse allowed without permission.

classification criteria(13). After a detailed clinical examination and laboratory investigations, patients were categorized under different clinical phenotypes. The clinical profile of 200 SLE patients has been summarized in Table-1. The disease severity was recorded by the SLEDAI-2K scores. Two hundred, age-matched females were included as healthy controls (HC). None of the controls reported a history of autoimmune disorder. About $5 \mathrm{ml}$ of blood in EDTA was collected; plasma was separated and quantified for sCD14, TNF $\alpha$, and IFN $\alpha$ levels by enzyme-linked immunosorbent assay (ELISA). The remaining blood samples were preserved with an equal amount of $8 \mathrm{M}$ urea at $-20^{\circ} \mathrm{C}$ until use for isolation of DNA. The study was approved by the Institutional Ethics Committee of SCB Medical College Cuttack, Odisha, India. Informed written consent was obtained from each patient.

\section{Genotyping of CD14 (C-159T) polymorphism}

Genomic DNA was extracted using the QIAamp DNA Blood Mini Kit (Qiagen, Hilden, Germany) according to the manufacturer's instructions. PCR followed by restriction fragment length polymorphism (PCR-RFLP) technique was employed to type the polymorphism at the promoter region (C-159T) of the CD14 gene (14). In brief, primer set (forward primer- 5'-GCC TCT GAC AGT TTA GTA ATC -3' and reverse primer-5'-GTG CCA ACA GAT GAG GTT CAC -3') was used for amplification of CD14 promoter region flanking C-159T polymorphic region which produced an amplicon of size $497 \mathrm{bp}$. The amplified product was digested by restriction enzyme HaeIII and based on the differential product size individuals genotypes for CD14 (C-159T), polymorphism was determined (CC: 198+156+143bp; TT: 299+198bp and CT: 299+198+156+143bp). Subsequently, 50 samples were randomly selected and genotyped through direct sequencing. The result of the sequencing and PCR-RFLP method was found to be in concordance. 
medRxiv preprint doi: https://doi.org/10.1101/2020.06.19.20136119; this version posted June 20, 2020. The copyright holder for this preprint (which was not certified by peer review) is the author/funder, who has granted medRxiv a license to display the preprint in perpetuity.

\section{Determination of plasma sCD14, IFN- $\alpha$, and TNF- $\alpha$.}

The plasma samples of 46 healthy controls and 78 SLE patients were available; sCD14, IFN- $\alpha$ and TNF- $\alpha$ levels were quantified by ELISA according to the manufacturer's instructions (sCD14 kit from R\&D Systems, Wiesbaden, Germany, IFN- $\alpha$ and TNF- $\alpha$ from Bender Med Systems, Vienna, Austria).

\section{In silico analysis}

Two online tools were used to investigate the functional relevance of CD14 promoter polymorphism (C-159T)) i) SNPinfo (FuncPred), and ii) RegulomeDB. As described earlier (15), the reference id of SNPs was entered into the online program of SNPinfo (FuncPred) (https://snpinfo.niehs.nih.gov/snpinfo/snpfunc.html) with the default setting. The output information was noted down for the possible functional effect of the genetic mutation.

To further strengthen the result of SNPinfo, another programRegulomeDB (http://regulomedb.org/)(16) was employed to investigate the functional relevance of CD14 promoter polymorphism. The result of the RegulomeDB categorizes into six groups (score-1: likely to affect binding and linked to the expression of a gene target; score-2: likely to affect binding; score-3: less likely to affect binding; score 4,5 and 6: minimal binding evidence). With no annotation data available, RegulomeDB allocates a score of 7 . In the present study, dbSNP ID was used for the analysis.

\section{Statistical analysis}

Genotype and allele frequency was calculated by direct counting. SNPalyze software (Dynacom, Japan) was employed to calculate the Hardy-Weinberg equilibrium. Fisher's test was 
medRxiv preprint doi: https://doi.org/10.1101/2020.06.19.20136119; this version posted June 20, 2020. The copyright holder for this preprint (which was not certified by peer review) is the author/funder, who has granted medRxiv a license to display the preprint in perpetuity.

All rights reserved. No reuse allowed without permission.

used for comparison of genotype, allele frequencies between SLE patients and healthy controls Wild type (CC) and major allele (C) were selected as reference $(\mathrm{OR}=1)$ and the other ORs and 95\% confidence interval were calculated relative to that reference (Fisher's exact test, $2 \times 2$ contingency tables). A P value of less than 0.01 was taken as significant. Distribution of plasma sCD14, IFN- $\alpha$, and TNF- $\alpha$ in different CD14 (C-159T) genotypes and clinical categories were assessed by D'Agostino \& Pearson omnibus normality test. Based on the results of the normality test, the association of genotype with plasma sCD14, TNF- $\alpha$, and IFN- $\alpha$ were analyzed by ANOVA or Kruskal-Wallis test followed by Tukey’s post-test. The Mann-Whitney analysis was employed to compare the mean plasma levels of sCD14, TNF- $\alpha$, and IFN- $\alpha$ in controls and SLE patients, or different clinical categories of SLE patients. All correlation analysis was performed by Spearman rank correlation test, and $P$ value less than 0.05 were considered as significant. Graphpad prism 7.05 software was used for these statistical analyses.

\section{Results}

\section{Baseline characteristics}

A total of 200 female SLE patients and the same number of healthy controls were enrolled in the current study. Baseline data are shown in Table-1. The age profile of patients and healthy controls were comparable. All patients were naïve, and the mean disease duration was 1.67 years. Similar to our earlier reports(17-19), renal involvement was observed in a majority of patients $(52 \%)$ followed by arthritis (44\%) and oral ulcer in (40\%) of patients.

\section{CD14 (C-159T) polymorphism is associated with SLE and lupus nephritis}

An association of CD14 (C-159T) polymorphism with SLE and its clinical manifestation was assessed. As shown in Table-2, the prevalence of homozygous mutant (TT) and heterozygous 
medRxiv preprint doi: https://doi.org/10.1101/2020.06.19.20136119; this version posted June 20, 2020. The copyright holder for this preprint (which was not certified by peer review) is the author/funder, who has granted medRxiv a license to display the preprint in perpetuity.

All rights reserved. No reuse allowed without permission.

(CT) was significantly higher in SLE patients compared to healthy controls (TT: $P=0.0001$, $\mathrm{OR}=3.39,95 \% \mathrm{CI}=1.76$ to $6.22 ; \mathrm{CT}: P<0.0001, \mathrm{OR}=3.26,95 \% \mathrm{CI}=1.85$ to 5.82$)$. Furthermore, the mutant allele $(\mathrm{T})$ was also significantly associated with SLE $(P=0.0009, \mathrm{OR}=1.62,95 \%$ $\mathrm{CI}=1.22$ to 2.13$)($ Table-2).

We analyzed whether CD14 promoter polymorphism was associated with clinical manifestations of SLE. As shown in Table-3, the frequency of homozygous mutant (TT) was significantly higher in patients with lupus nephritis compared to those without renal involvement $(P=0.0002, \mathrm{OR}=8.07,95 \% \mathrm{CI}=2.44$ to 22.53$)$. Distribution of mutant allele also showed a similar association $(P=0.001, \mathrm{OR}=1.32,95 \% \mathrm{CI}=1.22$ to 2.96$)$. However, the presence of $\mathrm{CD} 14(\mathrm{C}$ 159T) polymorphism was comparable among other clinical categories (data not shown).

\section{Functional relevance of CD14(C-159T) polymorphism}

To determine the functional relevance of CD14 (C-159T) polymorphism, plasma sCD14, IFN- $\alpha$, and TNF- $\alpha$ levels were assessed in healthy controls and SLE patients $(\mathrm{CC}=19 ; \mathrm{CT}=73$; TT=32). As shown in Figure-1A, homozygous mutant (TT) displayed significantly higher plasma sCD14 levels in comparison to the wild type $(\mathrm{CC})(P<0.0001)$ and heterozygous mutant $(\mathrm{CT})(P=0.001)$. Besides, homozygous mutant (TT) for CD14 (C-159T) polymorphism also displayed significantly higher plasma IFN- $\alpha(P<0.0001)$ (Figure-1B) and TNF- $\alpha(P<0.0001)$ (Figure-1C) compared to the wild types (CC).

\section{Functional relevance of CD14 (C-159T) polymorphism: in silico}

We observed a significant association between plasma levels of sCD14 and CD14 promoter polymorphism (C-159T). SNPinfo (FuncPred) and RegulomeDB online tools were used for validation of the above result in silico, and the output data are shown in Supplementary Table-1. 
medRxiv preprint doi: https://doi.org/10.1101/2020.06.19.20136119; this version posted June 20, 2020. The copyright holder for this preprint (which was not certified by peer review) is the author/funder, who has granted medRxiv a license to display the preprint in perpetuity.

All rights reserved. No reuse allowed without permission.

FuncPred program revealed a significant role of CD14 (C-159T) polymorphism on affecting the binding sites of transcription factors (TFBS). However, variation at -159 sites did not affect the miRNA binding location and found to have a regulatory potential (RegPot) of 0.26.

The functional relevance of CD14 polymorphism (C-159T) analysis with RegulomeDB revealed a score of ' $1 \mathrm{~b}$ ' which indicates a likely binding effect and which is linked to the expression of a gene target. Furthermore, it had annotation for eQTL + TF binding + any motif + DNase footprint + DNase peak, indicating a decisive role in the regulation of the CD14 gene (Supplementary Table-1).

\section{SLE patients and those with lupus nephritis had higher plasma sCD14, IFN- $\alpha$ and TNF- $\alpha$}

We demonstrated previously that the prevalence of the TT genotype was significantly higher in SLE patients and those with lupus nephritis. And this genotype (TT) was associated with higher plasma sCD14, IFN- $\alpha$, and TNF- $\alpha$ levels These observations alluded us to investigate the association of plasma levels of sCD14, IFN- $\alpha$, and TNF- $\alpha$ in SLE to disease manifestations. As shown in Figure-2, plasma levels of sCD14 (A), IFN- $\alpha$ (B) and TNF- $\alpha$ (C) were significantly higher in SLE patients compared to healthy controls $(P<0.0001)$. To assess the association of plasma parameters such as sCD14, TNF- $\alpha$, and IFN- $\alpha$ with lupus nephritis, SLE patients were divided into two group i) patients with lupus nephritis $(n=38)$ and ii) patients without lupus nephritis $(n=40)$. Subjects with lupus nephritis displayed significantly higher plasma sCD14 (D), IFN- $\alpha$ (E) and TNF- $\alpha(\mathrm{F})$ compared to the other group (sCD14: $P<0.0001$, IFN- $\alpha: P=0.001$, TNF- $\alpha: P=0.005$ ) (Figure-2).

24-hour proteinuria positively correlated with plasma levels of sCD14, IFN- $\alpha$, and TNF- $\alpha$ 
medRxiv preprint doi: https://doi.org/10.1101/2020.06.19.20136119; this version posted June 20, 2020. The copyright holder for this preprint (which was not certified by peer review) is the author/funder, who has granted medRxiv a license to display the preprint in perpetuity.

All rights reserved. No reuse allowed without permission.

As shown earlier, patients with lupus nephritis displayed higher plasma levels of sCD14, IFN- $\alpha$, and TNF- $\alpha$ compared to patients without renal involvement. We evaluated plasma parameters (sCD14, IFN- $\alpha$, and TNF- $\alpha$ ) with levels of proteinuria. As shown in Supplementary Figure-1, plasma levels of sCD14 (A), IFN- $\alpha$ (B) and TNF- $\alpha$ (C) correlated positively with 24-hr urinary protein.

\section{Correlations of Plasma sCD14 with SLEDAI -2K}

We evaluated the possibility of using sCD14 as a biomarker to assess disease severity. As shown in figure-3, plasma levels of sCD14 were significantly and positively correlated with SLEDAI scores $(P=0.002, \mathrm{r}=0.34)$. Complement components, $\mathrm{C} 3$ and $\mathrm{C} 4$, correlated negatively with sCD14 levels $(C 3: \mathrm{P}=0.003, \mathrm{r}=-0.33 ; \mathrm{C} 4: \mathrm{P}<0.0001, \mathrm{r}=-0.50)$. There was no correlation with ant-dsDNA. Further, we grouped SLE patients based on the severity of the disease and compared the mean sCD14 levels among them. As shown in Figure-3B, we observed elevated levels of sCD14 in patients with high disease activity (SLEDAI scores $\geq 12$ ) compared to those with mild to moderate activity (SLEDAI scores 5-12) $(\mathrm{P}=0.01)$.

\section{Plasma levels of SCD14 correlated positively with IFN- $\alpha$ and TNF- $\alpha$}

The cytokines, IFN- $\alpha$, and TNF- $\alpha$ have been observed to contribute to disease severity in SLE. We assessed the association of sCD14 with plasma levels of IFN- $\alpha$ and TNF- $\alpha$, Interestingly, sCD14 levels correlated positively with IFN- $\alpha(\mathrm{P}<0.0001, \mathrm{r}=0.76)$ and TNF- $\alpha(\mathrm{P}<0.0001, \mathrm{r}=0.55)$ (Supplementary Figure-2). Furthermore, levels of IFN- $\alpha$ and TNF- $\alpha$ also showed a significant positive correlation between them $(\mathrm{P}<0.0001, \mathrm{r}=0.51)$.

\section{Discussion}


medRxiv preprint doi: https://doi.org/10.1101/2020.06.19.20136119; this version posted June 20, 2020. The copyright holder for this preprint (which was not certified by peer review) is the author/funder, who has granted medRxiv a license to display the preprint in perpetuity.

All rights reserved. No reuse allowed without permission.

The pathogenesis of SLE is linked to the interaction between genetic susceptibility and environmental factors, notably infection, UV light, and drugs resulting in immune dysregulation. The present study demonstrates a significant association of CD14 (C-159T) polymorphism with SLE and lupus nephritis. It also provides evidence for a significant correlation between CD14 (C-159T) mutation with elevated plasma levels of $\operatorname{sCD} 14$, TNF- $\alpha$, and IFN- $\alpha$. Furthermore, we also observed that sCD14 levels can be utilized as a biomarker for assessing disease severity and lupus nephritis. The association of TNF- $\alpha$ and IFN- $\alpha$ in disease severity was reiterated. The results suggest that $\mathrm{CD} 14(\mathrm{C}-159 \mathrm{~T})$ variants may be one more genetic susceptibility factors in SLE and lupus nephritis.

Association of several candidate genes has been reported in SLE over the last three decades $(20,21)$. However, the literature on the role or association of the CD14 promoter polymorphism in SLE is limited. In a study in Tunisian, SLE patients demonstrated an association with homozygous mutant (TT) and minor allele (T) (22). We have corroborated the above observation in our cohort: a higher prevalence of CD14 mutants (CT and TT) and minor allele (T) in SLE patients visa vis healthy controls indicating a possible contributory role in the development of SLE. We analyzed the data based on clinical phenotypes and observed a significant association with lupus nephritis. This is a novel observation. The role of CD14 mutants in the development of lupus nephritis has not been assessed. A previous study highlighted the association of $\mathrm{T}$ allele with higher $\mathrm{mCD} 14$ expression(23). And our study demonstrated the association of TT and CT genotypes with elevated sCD14 levels. Furthermore, they were also associated with elevated plasma levels of TNF-a and IFN-a; the two inflammatory cytokines that contribute to the disease pathogenesis in SLE. Interestingly, the cytokines correlated positively with plasma sCD14 levels. In summary, mutants of CD14 contribute to 
medRxiv preprint doi: https://doi.org/10.1101/2020.06.19.20136119; this version posted June 20, 2020. The copyright holder for this preprint (which was not certified by peer review) is the author/funder, who has granted medRxiv a license to display the preprint in perpetuity.

All rights reserved. No reuse allowed without permission.

elevated sCD14, TNF- $\alpha$, IFN- $\alpha$, levels, which could be the contributing factors in disease severity and renal damage.

The number of studies is limited. Most published data indicate elevated sCD14 levels in SLE patients compared to healthy controls $(8,24,25)$. Active SLE patients have been observed with higher levels of sCD14 compared to inactive disease $(8,24)$, and reduction of sCD14 levels have been observed post treatment. But the relationship between $\operatorname{sCD} 14, \operatorname{IFN} \alpha$, and $\operatorname{TNF} \alpha$ has not been assessed.

We analyzed the data on sCD14 in lupus nephritis. The levels were significantly high compared to those without kidney involvement. Similar observations have been made in chronic kidney disease (26) and cystic kidney disease(27) but not in lupus nephritis. However, the cause and effect relationship is not known. Furthermore, higher levels of TNF- $\alpha$ and IFN- $\alpha$ were observed in lupus nephritis visa vis those without renal involvement, and they are known to be pathogenic. Elevated TNF- $\alpha$ and IFN- $\alpha$ have been observed in patients with kidney dysfunction related to various causes $(28,29)$. Infections are the environmental triggers that induce immune perturbation in SLE(30): CD14 recognizes a wide range of microbial pathogens that induce the production of inflammatory cytokines- $\mathrm{TNF}-\alpha$ and IFN- $\alpha$, and we hypothesize that this interaction, between infection and mutant CD14 results in inflammatory cytokine production that predisposes to the development of SLE and renal impairment.

The CD14 (C-159T) polymorphism is located in the promoter region of the CD14 gene. We assessed the sCD14 levels based on different genotypes of CD14(C 159T) in SLE and healthy controls. Mutants displayed higher sCD14 compared to wild type (CC), which corroborates with earlier observations $(10,11,31)$. A similar observation was also noted for 
medRxiv preprint doi: https://doi.org/10.1101/2020.06.19.20136119; this version posted June 20, 2020. The copyright holder for this preprint (which was not certified by peer review) is the author/funder, who has granted medRxiv a license to display the preprint in perpetuity.

All rights reserved. No reuse allowed without permission.

plasma levels of TNF- $\alpha$ and IFN- $\alpha$. The transition polymorphism $(\mathrm{C}>\mathrm{T})$ at the promoter region decreases Sp protein binding efficiency and enhances transcription levels of CD14, leading to a higher level of sCD14 (9). Furthermore, our in silico analysis demonstrated the variation site as a potential area for binding of transcription factors, indicating CD14 (C-159T) mutation as a critical functional polymorphism altering soluble CD14 levels in humans.

SLE is a clinically and serologically complicated disease, and its appropriate management depends on proper diagnosis and assessment of disease severity. Several molecules and antibodies have been proposed and assessed as biomarkers for distinct clinical phenotypes, and disease activity indices like SLEDAI-2K and BILAG have been widely used to assess disease severity. There has been the inconsistency of results of biomarkers among different populations which has been attributed to ethnicity, the differential prevalence of clinical phenotypes, and the coexistence of various infectious diseases(32). Thus, a population-specific biomarker could be a useful tool for predicting disease outcome. (33). In the present study, we explored the association between sCD14 with SLEDAI-2K, C3, C4, proteinuria, and other biomarkers of disease activity such as TNF- $\alpha$ and IFN- $\alpha(34,35)$. The sCD14 levels correlated positively and significantly with SLEDAI scores and 24 hours proteinuria; it inversely correlated with $\mathrm{C} 3$ and $\mathrm{C} 4$ levels, providing evidence that sCD14 could be a novel biomarker to assess disease activity. Interestingly, levels of sCD14 was significantly high in severe disease as assessed by SLEDAI-2K scores. This was reported in an earlier study which also observed a decrease in sCD14 levels post treatment (24).

\section{Conclusions}


medRxiv preprint doi: https://doi.org/10.1101/2020.06.19.20136119; this version posted June 20, 2020. The copyright holder for this preprint (which was not certified by peer review) is the author/funder, who has granted medRxiv a license to display the preprint in perpetuity.

All rights reserved. No reuse allowed without permission.

This study demonstrates a significant association between CD14 promoter polymorphism (C-159T), increased sCD14 levels with SLE, lupus nephritis, and SLEDAI-2K scores. Plasma sCD14 could be used as a novel biomarker to assess disease severity. Further studies in different populations can validate our observation.

\section{References}

1. Kaul A, Gordon C, Crow MK, Touma Z, Urowitz MB, van Vollenhoven R, et al. Systemic lupus erythematosus. Nat Rev Dis Primers. 2016;2:16039.

2. Medzhitov R, Janeway CA, Jr. Innate immunity: impact on the adaptive immune response. Curr Opin Immunol. 1997;9(1):4-9.

3. Doaty S, Agrawal H, Bauer E, Furst DE. Infection and Lupus: Which Causes Which? Curr Rheumatol Rep. 2016;18(3):13.

4. Chen JQ, Szodoray P, Zeher M. Toll-Like Receptor Pathways in Autoimmune Diseases. Clin Rev Allergy Immunol. 2016;50(1):1-17.

5. Dobrovolskaia MA, Vogel SN. Toll receptors, CD14, and macrophage activation and deactivation by LPS. Microbes Infect. 2002;4(9):903-14.

6. Haziot A, Ferrero E, Kontgen F, Hijiya N, Yamamoto S, Silver J, et al. Resistance to endotoxin shock and reduced dissemination of gram-negative bacteria in CD14-deficient mice. Immunity. 1996;4(4):407-14.

7. Chow JC, Young DW, Golenbock DT, Christ WJ, Gusovsky F. Toll-like receptor-4 mediates lipopolysaccharide-induced signal transduction. J Biol Chem. 1999;274(16):10689-92.

8. Nockher WA, Wigand R, Schoeppe W, Scherberich JE. Elevated levels of soluble CD14 in serum of patients with systemic lupus erythematosus. Clin Exp Immunol. 1994;96(1):15-9.

9. LeVan TD, Bloom JW, Bailey TJ, Karp CL, Halonen M, Martinez FD, et al. A common single nucleotide polymorphism in the CD14 promoter decreases the affinity of Sp protein binding and enhances transcriptional activity. J Immunol. 2001;167(10):5838-44.

10. Baldini M, Lohman IC, Halonen M, Erickson RP, Holt PG, Martinez FD. A Polymorphism* in the 5' flanking region of the CD14 gene is associated with circulating soluble CD14 levels and with total serum immunoglobulin E. Am J Respir Cell Mol Biol. 1999;20(5):976-83.

11. Hubacek JA, Rothe G, Pit'ha J, Skodova Z, Stanek V, Poledne R, et al. C(-260)-->T polymorphism in the promoter of the CD14 monocyte receptor gene as a risk factor for myocardial infarction. Circulation. 1999;99(25):3218-20.

12. Danchenko N, Satia JA, Anthony MS. Epidemiology of systemic lupus erythematosus: a comparison of worldwide disease burden. Lupus. 2006;15(5):308-18. 
medRxiv preprint doi: https://doi.org/10.1101/2020.06.19.20136119; this version posted June 20, 2020. The copyright holder for this preprint (which was not certified by peer review) is the author/funder, who has granted medRxiv a license to display the preprint in perpetuity.

All rights reserved. No reuse allowed without permission.

13. Petri M, Orbai AM, Alarcón GS, Gordon C, Merrill JT, Fortin PR, et al. Derivation and validation of the Systemic Lupus International Collaborating Clinics classification criteria for systemic lupus erythematosus. Arthritis and rheumatism. 2012;64(8):2677-86.

14. Koppelman GH, Reijmerink NE, Colin Stine O, Howard TD, Whittaker PA, Meyers DA, et al. Association of a promoter polymorphism of the CD14 gene and atopy. Am J Respir Crit Care Med. 2001;163(4):965-9.

15. Xu Z, Taylor JA. SNPinfo: integrating GWAS and candidate gene information into functional SNP selection for genetic association studies. Nucleic acids research. 2009;37(Web Server issue):W600-5.

16. Boyle AP, Hong EL, Hariharan M, Cheng Y, Schaub MA, Kasowski M, et al. Annotation of functional variation in personal genomes using RegulomeDB. Genome research. 2012;22(9):1790-7.

17. Panda AK, Parida JR, Tripathy R, Pattanaik SS, Ravindran B, Das BK. Low producer MBL genotypes are associated with susceptibility to systemic lupus erythematosus in Odisha, India. Hum Immunol. 2012.

18. Panda AK, Parida JR, Tripathy R, Pattanaik SS, Ravindran B, Das BK. Mannose binding lectin: a biomarker of systemic lupus erythematosus disease activity. Arthritis Res Ther. 2012;14(5):R218.

19. Mahto H, Tripathy R, Meher BR, Prusty BK, Sharma M, Deogharia D, et al. TNF-alpha promoter polymorphisms (G-238A and G-308A) are associated with susceptibility to Systemic Lupus Erythematosus (SLE) and P. falciparum malaria: a study in malaria endemic area. Sci Rep. 2019;9(1):11752.

20. Deng Y, Tsao BP. Genetic susceptibility to systemic lupus erythematosus in the genomic era. Nat Rev Rheumatol. 2010;6(12):683-92.

21. Ceccarelli F, Perricone C, Borgiani P, Ciccacci C, Rufini S, Cipriano E, et al. Genetic Factors in Systemic Lupus Erythematosus: Contribution to Disease Phenotype. J Immunol Res. 2015;2015:745647.

22. Dhaouadi T, Sfar I, Haouami Y, Abdelmoula L, Turki S, Hassine LB, et al. Polymorphisms of Tolllike receptor-4 and CD14 in systemic lupus erythematosus and rheumatoid arthritis. Biomark Res. 2013;1(1):20.

23. Eng $\mathrm{HL}$, Wang $\mathrm{CH}$, Chen $\mathrm{CH}$, Chou $\mathrm{MH}$, Cheng $\mathrm{CT}$, Lin TM. A CD14 promoter polymorphism is associated with CD14 expression and Chlamydia-stimulated TNF alpha production. Genes Immun. 2004;5(5):426-30.

24. Egerer K, Feist E, Rohr U, Pruss A, Burmester GR, Dorner T. Increased serum soluble CD14, ICAM1 and E-selectin correlate with disease activity and prognosis in systemic lupus erythematosus. Lupus. 2000;9(8):614-21.

25. Posso-Osorio I, Echeverry, A., Aguirre-Valencia, D., Castaño, G., Tobón, G. AB0498 Soluble CD14 (PRESEPSIN) as a potential biomarker to discriminate infection vs. activity in patients with systemic lupus erythematosus. Annals of the Rheumatic Diseases. 2017;76.

26. Naicker SD, Cormican S, Griffin TP, Maretto S, Martin WP, Ferguson JP, et al. Chronic Kidney Disease Severity Is Associated With Selective Expansion of a Distinctive Intermediate Monocyte Subpopulation. Front Immunol. 2018;9:2845.

27. Zhou J, Ouyang X, Cui X, Schoeb TR, Smythies LE, Johnson MR, et al. Renal CD14 expression correlates with the progression of cystic kidney disease. Kidney Int. 2010;78(6):550-60.

28. Ernandez T, Mayadas TN. Immunoregulatory role of TNFalpha in inflammatory kidney diseases. Kidney Int. 2009;76(3):262-76.

29. Cattran DC. Interferon therapy: a double-edged sword? Am J Kidney Dis. 1999;33(6):1174-6.

30. Jung JY, Suh $\mathrm{CH}$. Infection in systemic lupus erythematosus, similarities, and differences with lupus flare. Korean J Intern Med. 2017;32(3):429-38.

31. Nieto-Fontarigo JJ, Salgado FJ, San-Jose ME, Cruz MJ, Casas-Fernandez A, Gomez-Conde MJ, et al. The CD14 (-159 C/T) SNP is associated with sCD14 levels and allergic asthma, but not with CD14 expression on monocytes. Sci Rep. 2018;8(1):4147. 
medRxiv preprint doi: https://doi.org/10.1101/2020.06.19.20136119; this version posted June 20, 2020. The copyright holder for this preprint (which was not certified by peer review) is the author/funder, who has granted medRxiv a license to display the preprint in perpetuity.

All rights reserved. No reuse allowed without permission.

32. Wang X, Ward PA. Opportunities and challenges of disease biomarkers: a new section in the Journal of Translational Medicine. J Transl Med. 2012;10:220.

33. Liu CC, Kao AH, Manzi S, Ahearn JM. Biomarkers in systemic lupus erythematosus: challenges and prospects for the future. Ther Adv Musculoskelet Dis. 2013;5(4):210-33.

34. Idborg H, Eketjall S, Pettersson S, Gustafsson JT, Zickert A, Kvarnstrom M, et al. TNF-alpha and plasma albumin as biomarkers of disease activity in systemic lupus erythematosus. Lupus Sci Med. 2018;5(1):e000260.

35. Mathian A, Mouries-Martin S, Dorgham K, Devilliers H, Yssel H, Garrido Castillo L, et al. Ultrasensitive serum interferon-alpha quantification during SLE remission identifies patients at risk for relapse. Ann Rheum Dis. 2019;78(12):1669-76.

\section{Figure legends}

Figure-1. Association of CD14(C-159T) polymorphism with plasma sCD14, IFN- $\alpha$ and TNF- $\alpha$. Plasma concentrations of sCD14, IFN- $\alpha$ and TNF- $\alpha$ in healthy controls and SLE patients were measured by commercial kit. Based on availability plasma, 78 SLE patients (SLE) and 46 healthy controls (HC) were quantified for sCD14 (A), IFN- $\alpha$ (B) and TNF- $\alpha$ (C) and correlated with CD14 (C-159T) polymorphism. Numbers of samples from each genotype are shown in box. Mean plasma levels in different genotypes were compared by Analysis of Variance (ANOVA) or Kruskal-Wallis test as appropriate followed by Turkey post-test. $P$ value less than 0.05 was considered as significant.

Figure-2. Plasma levels of sCD14, IFN- $\alpha$ and TNF- $\alpha$ in SLE patients. Plasma samples of healthy controls $(n=46)$ and SLE patients $(n=78)$ were quantified for sCD14, IFN- $\alpha$ and TNF- $\alpha$ levels by ELISA according to manufacturer's instructions. SLE patients displayed significantly higher concentrations of sCD14 (A), IFN- $\alpha$ (B) and TNF- $\alpha$ (C) compared to healthy controls. 
medRxiv preprint doi: https://doi.org/10.1101/2020.06.19.20136119; this version posted June 20, 2020. The copyright holder for this preprint (which was not certified by peer review) is the author/funder, who has granted medRxiv a license to display the preprint in perpetuity.

All rights reserved. No reuse allowed without permission.

Based on kidney dysfunction clinical phenotype, SLE patients were further categorized in to lupus nephritis ${ }^{+}$and lupus nephritis'. Lupus patients with nephritis displayed significantly higher sCD14 (D), IFN- $\alpha$ (E) and TNF- $\alpha$ (F) compared to those free of kidney dysfunction. Dots represent individual samples; bars show the mean \pm SEM. Mann-Whitney test was used to compare plasma concentrations among different clinical categories. $P$ values less than 0.05 was considered as significant.

Figure-3 Correlation of plasma sCD14 with SLEDAI scores, C3, C4 and anti-dsDNA.

Plasma sCD14 levels were quantified in SLE patients $(n=78)$ and correlated with SLEDAI (A), C3 (C), C4 (D) and anti-dsDNA (E). A positive correlation was observed between plasma sCD14 and SLEDAI, C3 and C4. However, no correlation was noticed among sCD14 and anti-dsDNA. Further patients with severe disease phenotype displayed significantly higher sCD14 compared to moderate severity (B). Dots represent individual sample. Correlation analysis was performed by Spearman rank correlation coefficient. A $P$ value less than 0.05 was considered as significant. 
medRxiv preprint doi: https://doi.org/10.1101/2020.06.19.20136119; this version posted June 20, 2020. The copyright holder for this preprint (which was not certified by peer review) is the author/funder, who has granted medRxiv a license to display the preprint in perpetuity.

All rights reserved. No reuse allowed without permission.

Table-1. Clinical characteristics of SLE patients and healthy controls.

\begin{tabular}{lll}
\hline Clinical profiles & SLE $(n=200)$ & Healthy control $(n=200)$ \\
\hline Sex (male/ female) & $0 / 200$ & $0 / 200$ \\
Age (mean \pm SD) & $28.23 \pm 8.48$ & $29.24 \pm 6.48$ \\
Duration of disease (mean \pm SD) & $1.67 \pm 2.32$ & - \\
Clinical Profile: & & - \\
Photosensitivity & $48(24)$ & - \\
Malar rash & $71(35.5)$ & - \\
Discoid rash & $34(17)$ & - \\
Oral ulcer & $80(40)$ & - \\
Arthritis & $88(44)$ & - \\
NPSLE & $37(18.5)$ & - \\
Myocarditis & $18(9)$ & - \\
AIHA & $32(16)$ & \\
\hline
\end{tabular}




\begin{tabular}{lll}
\hline Serositis & $36(18)$ & - \\
Nephritis & $104(52)$ & - \\
Pneumonitis & $15(7.5)$ & -
\end{tabular}

Note. Data are no. (\%) of participants unless otherwise specified. NPSLE, Neuropsychiatric systemic lupus erythematosus; AIHA, autoimmune hemolytic anemia.

Table-2 Prevalence of CD14 (C-159T) polymorphism in SLE patients and healthy controls.

\begin{tabular}{lllll}
\hline $\begin{array}{l}\text { Genotype/Allele } \\
\text { Genotype }\end{array}$ & HC (n=200) & SLE (n=200) & $P$ value & OR (95\% CI) \\
\hline CC & $58(29)$ & $22(11)$ & 1 & ref \\
CT & $100(50)$ & $124(62)$ & $<0.0001$ & $3.26(1.85$ to 5.82$)$ \\
TT & $42(21)$ & $54(27)$ & 0.0001 & $3.39(1.76$ to 6.22$)$ \\
Allele & & & & \\
C & $216(54)$ & $168(42)$ & 1 & Ref \\
T & $184(46)$ & $232(58)$ & 0.0009 & $1.62(1.22$ to 2.13$)$ \\
\hline
\end{tabular}

Note. Data are no. (\%) of participants unless otherwise specified. HC: healthy control; SLE: systemic lupus erythematosus; OR: odds ratio; 95\% CI: 95\% confidence interval. Distribution of genotypes and allele were compared by Fisher exact test. 
Table-3 Distribution of CD14 (C-159T) polymorphism in SLE patients with lupus nephritis.

\begin{tabular}{lllll}
\hline Genotype/Allele & $\mathrm{LN}^{-}(\mathrm{n}=96)$ & $\begin{array}{l}\mathrm{LN}^{+} \\
(\mathrm{n}=104)\end{array}$ & $P$ value & OR (95\% CI) \\
\hline Genotype & $17(18)$ & $5(4)$ & 1 & ref \\
CC & $63(66)$ & $61(59)$ & 0.03 & $3.29(1.23$ to 8.49$)$ \\
CT & $16(16)$ & $38(37)$ & 0.0002 & $8.07(2.44$ to 22.53$)$ \\
TT & & & & \\
Allele & $97(51)$ & $71(34)$ & 1 & ref \\
C & $95(49)$ & $137(66)$ & 0.001 & $1.32(1.22$ to 2.96$)$ \\
T & & & & \\
\hline
\end{tabular}

Note. Data are no. (\%) of participants unless otherwise specified. $\mathrm{LN}^{+}$: patients with lupus nephritis; $\mathrm{LN}^{-}$: patients without lupus nephritis manifestation; OR: odds ratio; 95\% CI: 95\% confidence interval. Distribution of genotypes and allele were compared by Fisher exact test. 
medRxiv preprint doi: https://doi.org/10.1101/2020.06.19.20136119; this version posted June 20, 2020. The copyright holder for this preprint (which was not certified by peer review) is the author/funder, who has granted medRxiv a license to display the preprint in perpetuity.

All rights reserved. No reuse allowed without permission. 


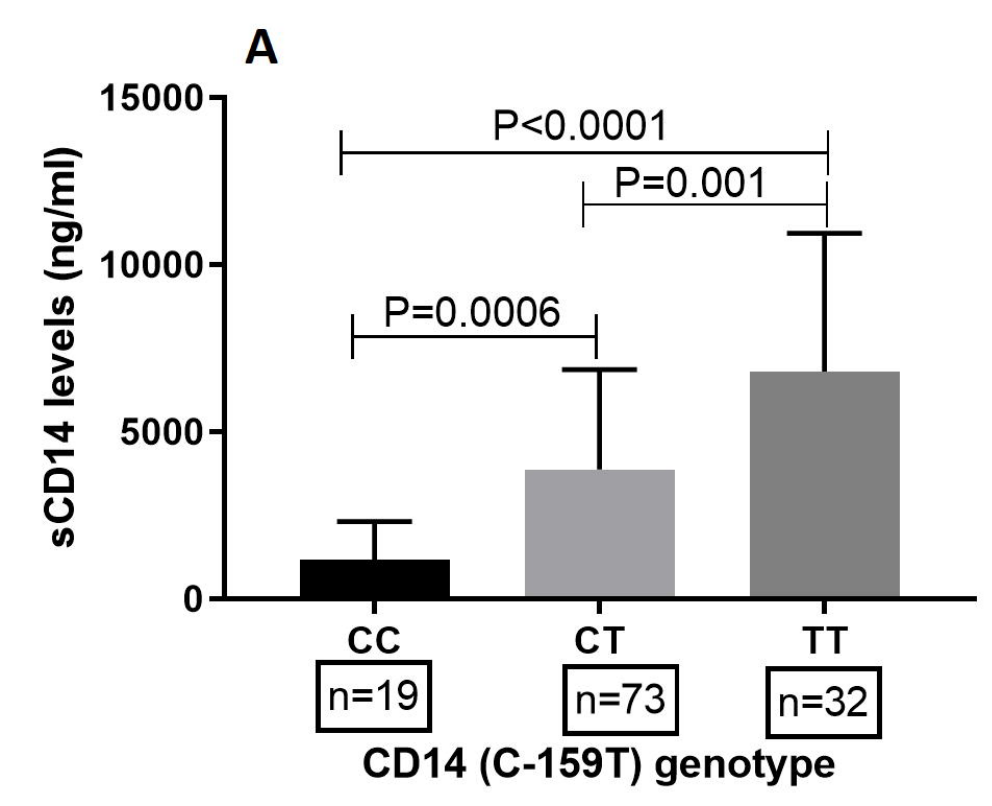




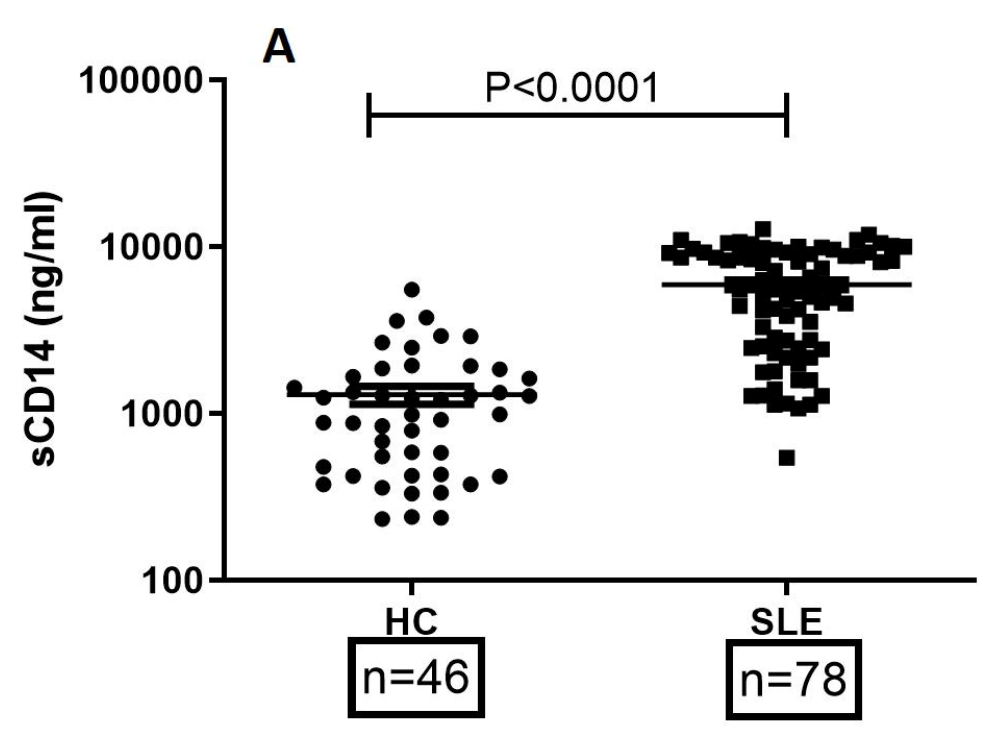

Clinical categories

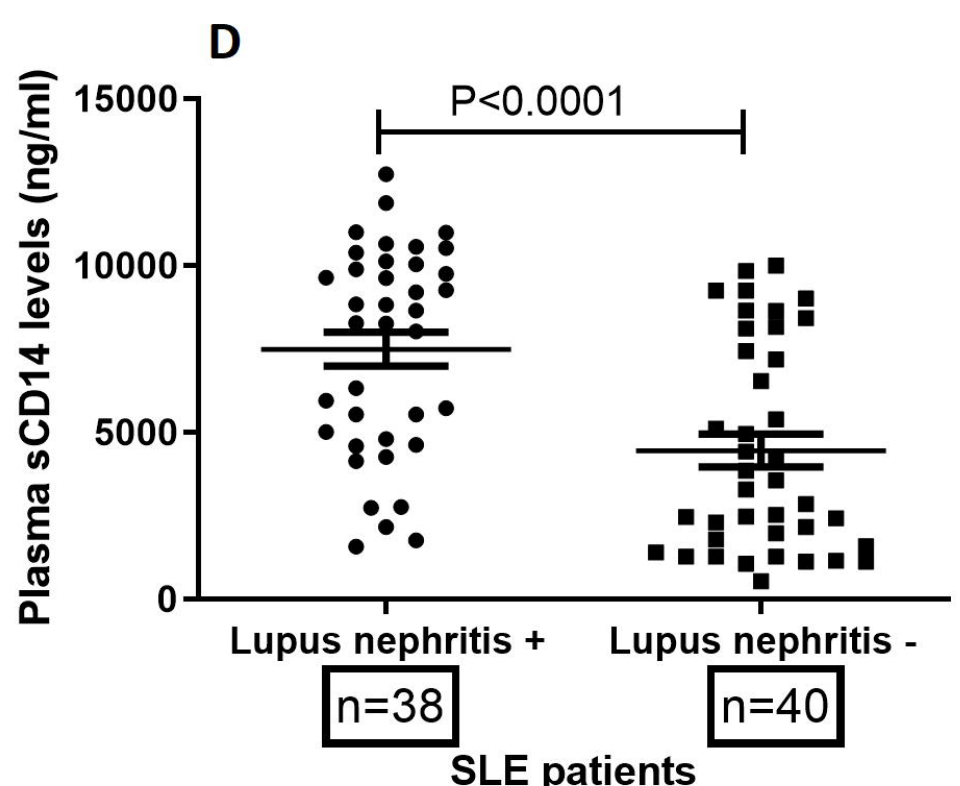

SLE patients
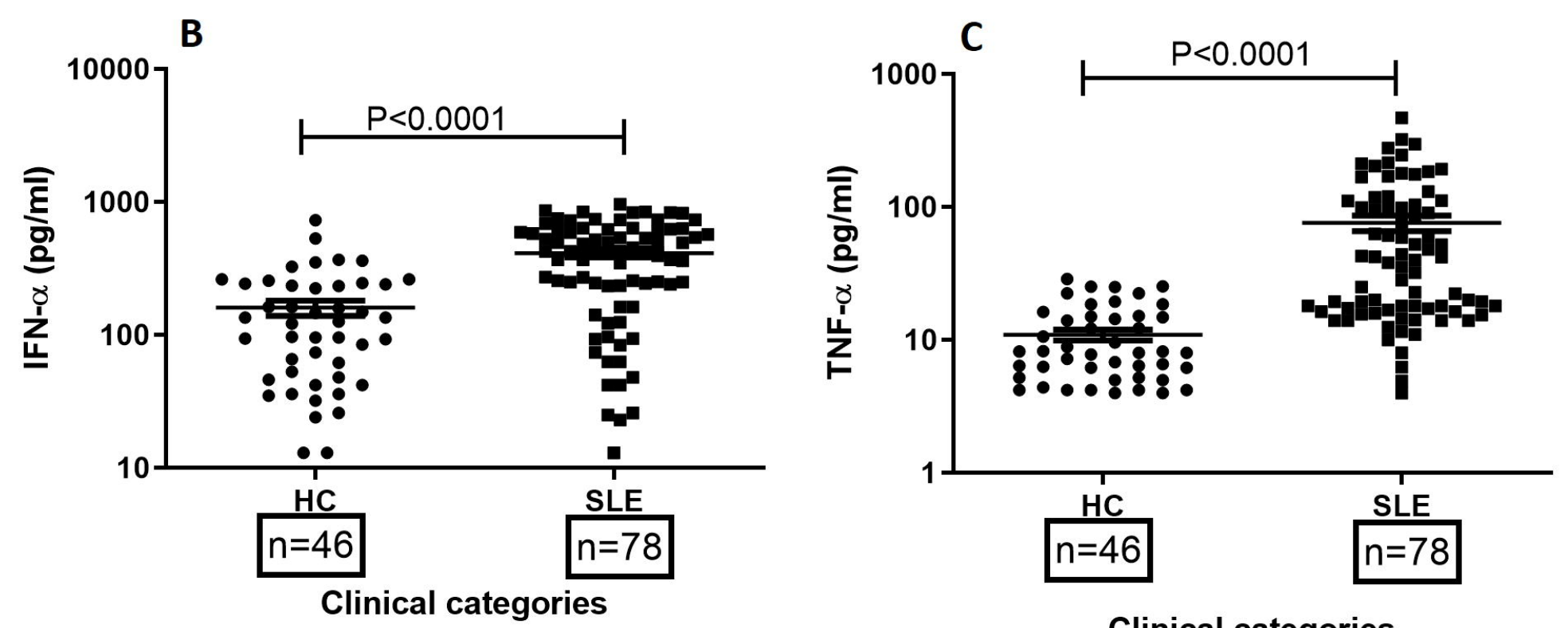

Clinical categories

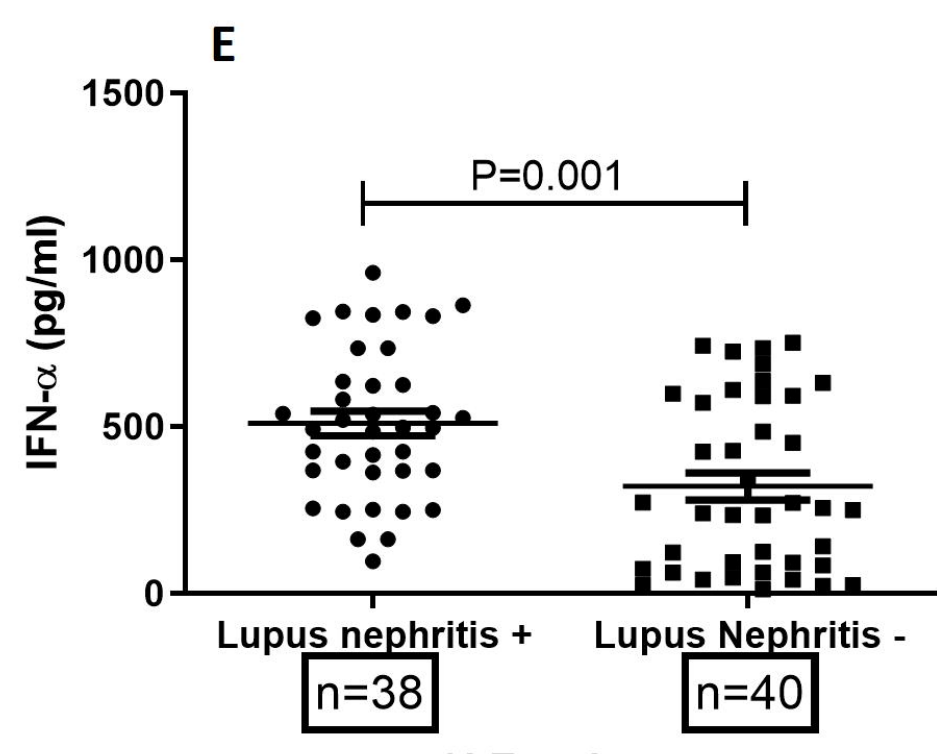

SLE patients

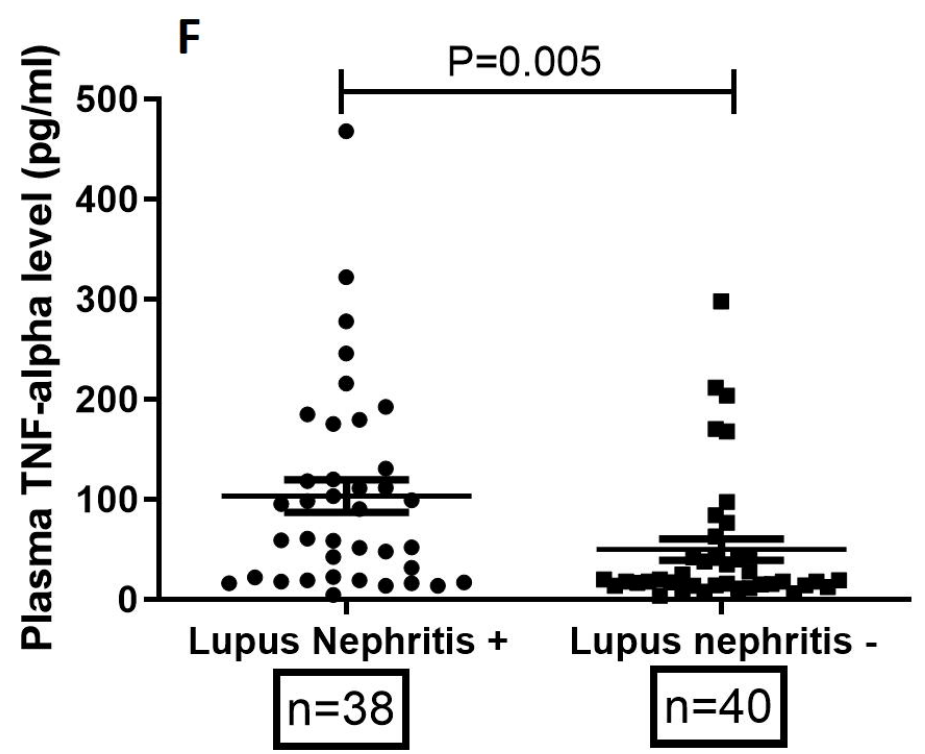

SLE patients 
